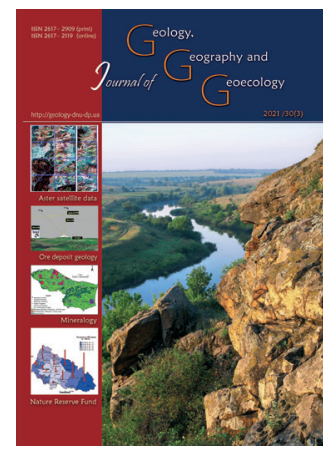

\section{Journal of Geology. Geograpky and Geoecology}

ISSN 2617-2909 (print)

ISSN 2617-2119 (online)

Journ. Geol. Geograph. Geology, 30(3), 528-538. doi: $10.15421 / 112148$

Mansurov M. I., Kerimli U. I., Guseynov A. I.

Geol. Geograph. Geoecology, 30(3), 528-538

\title{
Conditions of localization and patterns of distribution of gold-poly-metal mineralization of the Dagkesaman deposits (Lesser Caucasus, Azerbaijan)
}

\author{
Mamoy I. Mansurov, Ulker I. Kerimli, Azer I. Guseynov \\ Baku State University, Baku, the Republic of Azerbaijan, e-mail: mamoy_mansurov@mail.ru
}

Received: 06.11.2020

Received in revised form: 08.01.2021

Accepted: 19.03.2021

\begin{abstract}
We studied the structural-morphological types and mineral composition of ore bodies, stages of ore development and conditions of development of the deposits. The research revealed significant elements of the corresponding conditions of localization of gold-polymetallic mineralization, the most characteristic being albitophyre subvolcanic bodies and steeply-dipping damages related to
\end{abstract} them. According to the structural-morphologic peculiarities, the ore bodies should be united under three categories: 1) simple vein; 2) complex vein; 3) veinlet-impregnation types. The positions of gold ore bodies and their morphological peculiarities were found to be determined by structural factors. Presence of small ruptures, differently-oriented systems of fractures and faults, which run across the area, gentle curves of these systems and other structural elements -all of this promotes gold ore development. There research determined aureoles of ore-containing altered rocks (serialization, chloritization, kaolization and calcinations, and limonitization from hypergenical zones) and presence of zonal structure. Gold-productive areas were identified as the quartz-pyrite association with disperse gold, and especially, the second mineral association where there is a notable close paragenetic connection between noticeable gold and chalcopyrite-galena parageneis of polymetallic stage. In the process of ore development, the physical-chemical conditions have presumably changed from average deep (quartz-pyrite-sericite) to shallow (quartz-galena- sphalerite-gold ore) and close-to-the-surface (quartz-chalcocite-hematite). Gold that occurs with all the mentioned minerals of this stage has developed in the temperature interval of $220-160^{\circ} \mathrm{C}$. The study found the ores to be complex, containing the following dditional elements: $\mathrm{Fe}, \mathrm{Cu}, \mathrm{S}, \mathrm{Bi}, \mathrm{Zn}, \mathrm{Pb}$, As, Se, Te. The main fossil component is gold. Industrially valuable are also cadmium, zink, copper and silver, found in the ores. We found the following morphological types of grains of native gold: homogenous, zonal, mono-granular, spotted, which are of great significance for concluding on genesis of the deposits, prognoses, explorations and assessments.

Keywords: Dagkesaman, gold-polymetallic, structural-morphological, sulfides, gold mineralization, ore development

\section{Умови локалізації та закономірності розміщення золото-поліметалічного зруденіння Дагкесаманского родовища (Малий Кавказ, Азербайджан)}

\author{
Мамой I. Мансуров, Улькер I. Керімлі, Азер I. Гусейнов
}

Бакинський державний університет, Азербайджанська Республіка, Баку, е-таil: татоу_mansurov@таil.ru

\begin{abstract}
Анотація. Досліджено структурно-морфологічні типи та мінеральний склад рудних тіл, стадийність рудоутворення і умови формування родовища. Виділено суттєві елементи відповідних умов локалізації золото-поліметалічної мінералізації, найбільш характерними серед яких є альбітофірові субвулканичні тіла і крутопадаючі пов'язані порушення. За структурноморфологічними особливостями рудні тіла були об'єднані в три групи: 1) прості жильні; 2) складні жильні; 3) прожілкововкраплені. Встановлено, що позиції золоторудних тіл і їх морфологічні особливості визначаються структурними чинниками. Наявність дрібних розривів, перетин різноспрямованих систем тріщинуватості і розривів, пологі вигини останніх і інші структурні елементи - все це сприяє локалізації золотого зруденіння. Було встановлено ореоли рудовміщуючих змінених порід (серіцітізація, хлорітізаціі, каолінізація і кальцітізація, з гіпергенних змін - лімонітізація), наявність зональної будови. Встановлено, що продуктивною на золото є кварц-піритова асоціація з дисперсним золотом і, особливо, друга мінеральна асоціація, у якій підкреслюється тісний парагенетичних зв'язок гіпогенних видимого золота з халькопирит-галенітовим парагенезісом поліметалічної стадії. Висловлено припущення, що в процесі рудоутворення фізико-хімічні умови змінювалися від середньоглибиннх (кварц-піритсеріцітових) до малоглибинних (кварц-галеніт-сфалерит-золоторудних) та близькоповерхневих (кварц-халькозин-гематитових). Золото, що зустрічається з усіма згаданими мінералами цісї стадії. утворилося в температурному інтервалі $220-160{ }^{\circ} \mathrm{C}$. Виявлено, що руди полікомпонентні. Визначено елементи-домішки: $\mathrm{Fe}, \mathrm{Cu}, \mathrm{S}, \mathrm{Bi}, \mathrm{Zn}, \mathrm{Pb}, \mathrm{As}, \mathrm{Se}, \mathrm{Te}$. Основним корисним компонентам є золото. Промислове значення в рудах мають також свинець, цинк, мідь і срібло. Виявлено наступні морфологічні типи зерен самородної золота: однорідне, зональне, монозернисте, плямисте, які мають велике практичне значення для з'ясування генезису родовища, прогнозних і пошуковооціночних робіт.
\end{abstract}

Ключові слова: Дагкесаман, золото-поліметалічний, структурно-морфологічний, сульфіди, золота мінералізація, рудоутворення. 


\section{Introduction.}

The epithermal high sulfidation deposits of Dagkesaman contain some of the country's main deposits, located in the Kazakh ore district (Azerbaujan), and promising deposits of epithermal gold polymetallic ores. These deposits belong to the Lesser Caucasus, lying in the central part of the Tetis metallogenic belt (Fig. 1). Deposits are in the Jurassic-Cretaceous LokKarabakh magmatic arch, developed as a result of the subduction of the Neo-Tethys Ocean along the outskirts of Eurasia (Geology of Azerbaijan, 2005).

The Kazakh ore district within the Lesser Caucasus, which includes the Dagkesaman deposits, is of great interest for discovering gold polymetallic ores, as indicated by the presence of areas containing polymetallic gold ores and individual manifestations of ores. The tectonic position of the deposits is confined to the Kazak transversal depression in the western segment of the Lok-Karabakh island arc (Geology of Azerbaijan, 2005). The deposits were studied from the surface to the depth of $300 \mathrm{~m}$ in numerous wells and mining works.

The main objectives of the study were the conditions of localization and patterns of the Dagkesaman polymetallic gold ore deposits and the possibility of reconsideration of the perspective of its future exploration.

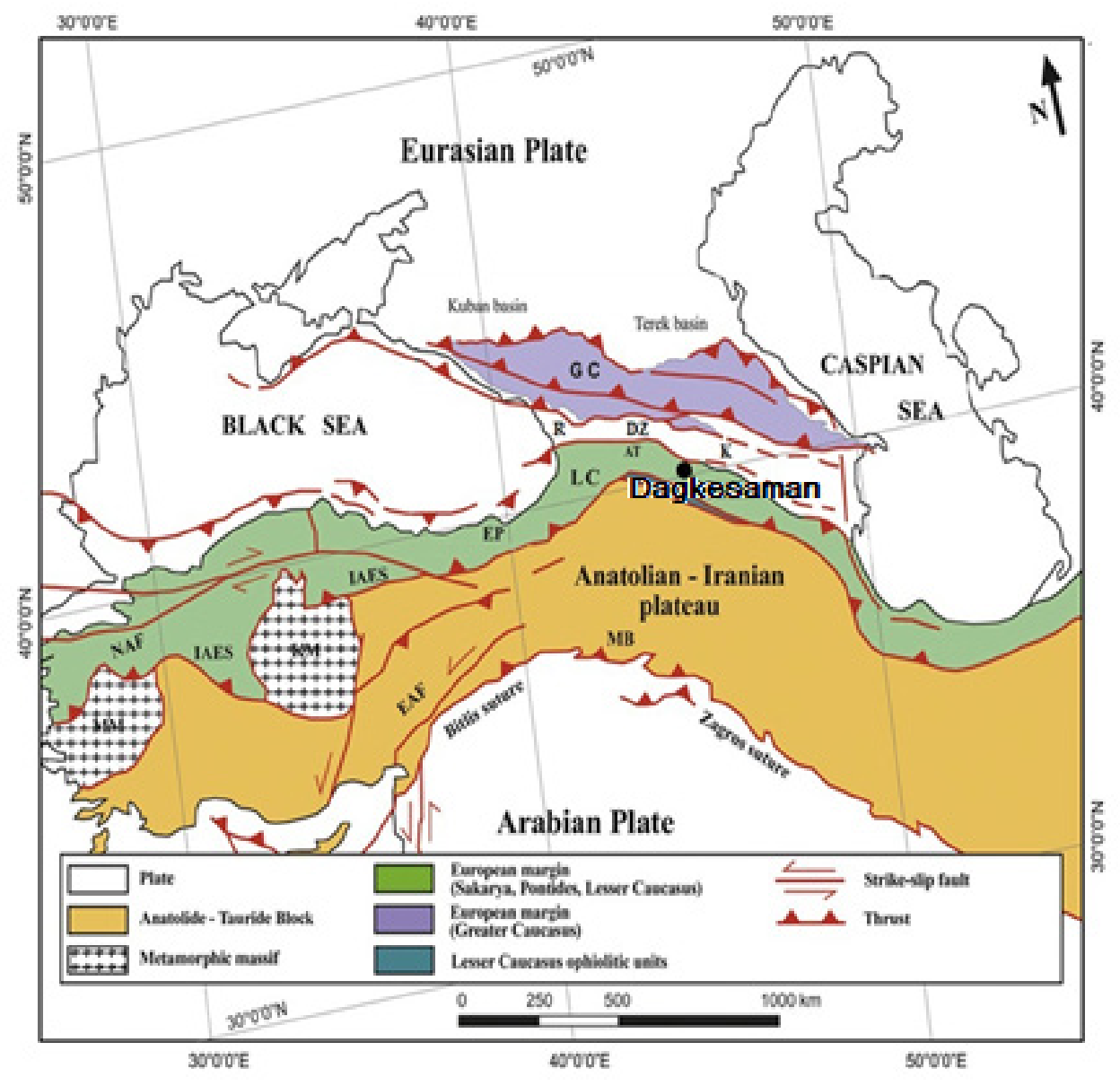

Fig. 1. Tectonic map of the zone of Arabia-Eurasia collision. Location of the Dagkesaman deposits is shown by circle (Sosson et al. 2010). Сокращения: GC-Greater Caucasus; LC-Lesser Caucasus; AT- Adjara-Trialeti; R- Rioni; Dz-Dzirula; K-Kura; MB - Mus basin; EP - Eastern Pontides; KM - Kırşehir Massif; EAF - Eastern Anatolia Fault; NAF - North-Anatolia fault;; IAES- İzmir Ankara-Erzincan suture; MM-Menderes Massif.

\section{Materials and methods.}

The tasks were solved using the materials mainly collected by the authors personally during the study of the ore field and deposits. The basis for the structural studies in the ore fields and deposits were the data of detailed mapping of the surface, carried out in the scales of 1:2,000 and 1:5,000, documents of underground mining and core samples of the wells. We performed lithologic-petrographic studies of ore-containing rocks and formation analysis of magmatic complexes.

In the study of samples of rocks and ores, we used optical microscopy, scanning electron microscopy and $\mathrm{X}$-ray-spectral microanalysis. 
Mineralogical composition of the ores and chemical composition of ore and non-ore minerals were analyzed using modern special instrumental mineralogical operation system QEMSCAN ${ }^{\mathrm{TM}}$, with application of electrone microscope, $\mathrm{x}$-ray-fluorescent analisys and microspectral sensing. Silicate chemical analysis was conducted in the laboratory of İzmir University, Turkey.

To develop graphic illustrations, we used software Corel Draw Graphics Suite, Surfer, ArcGIS.

Specifics of geological structure of the deposits. The deposits are located within the contour of the ore field of the same name in the eastern part of the Kazakh ore-bearing district. Ore-containing rocks are of volcanogenic basalt-andesite-rhyolite formation of Cenomanian-Upper Santonian (Abdullaev et al., 1988). Within the borders of the deposits, only the Upper Turonian-Lower Coniacian layer is exposed, which is $800 \mathrm{~m}$ thick and represented by lavas of andesites and andesite-dacites alternating with tufa, making up the elevated tectonic block. It is this layer that contains ores of the Dagkesaman deposits (Fig. 2). Within the borders of the deposits, the thickness of lava flows and the layers of tufa which divide it varies 20 to $100 \mathrm{~m}$. According to the data of the wells, the lava flows and tufa layers are distributed down to $450 \mathrm{~m}$ depth. Orecontaining rocks are torn by numerous large dikes, rarer diabases that are subvolcanic facies of the same series of andesite-basalts (Abdullaev et al., 1988).

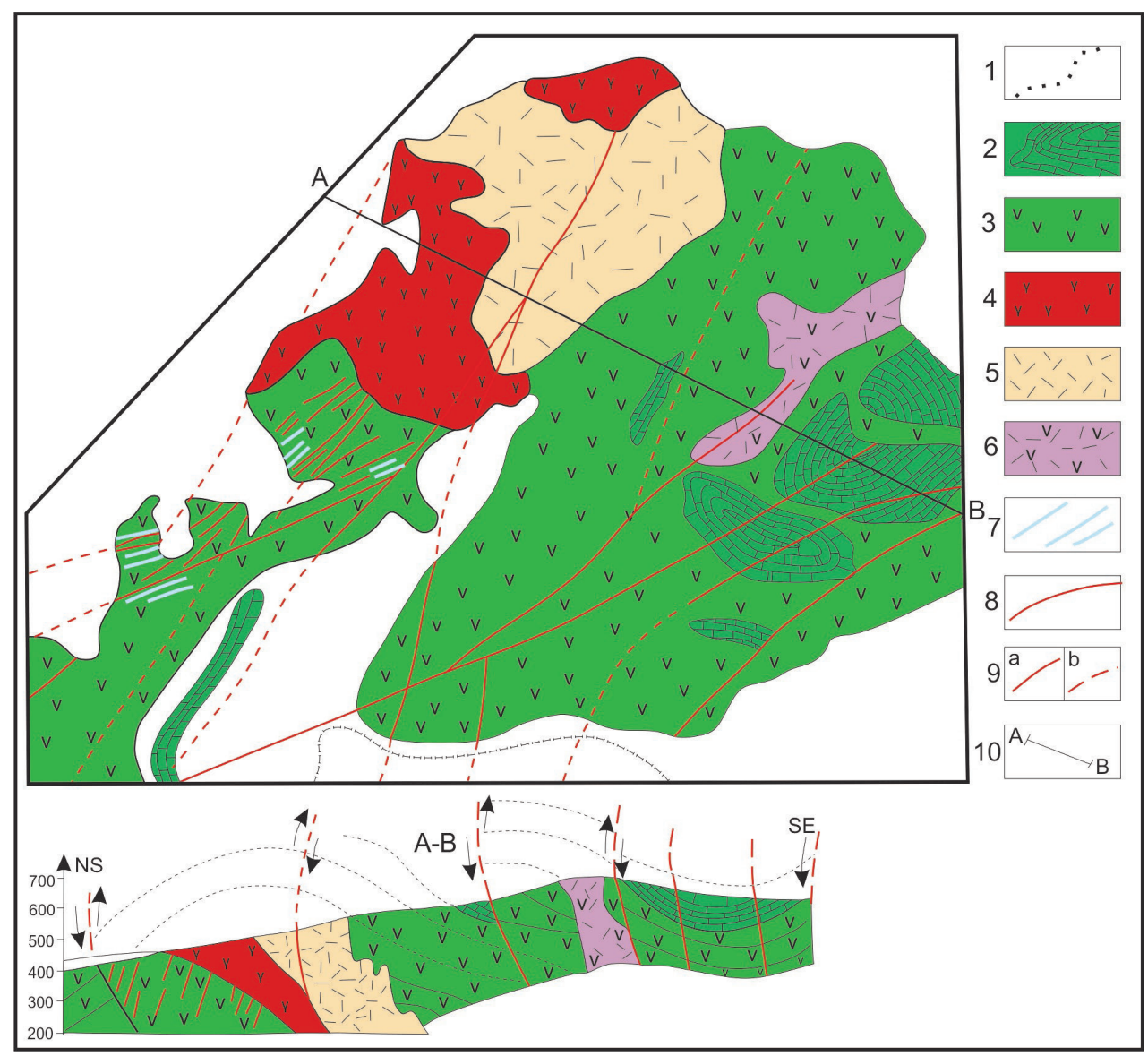

Fig. 2. Geological map of the Dagkesaman gold-poly metal deposits: 1 - current deposits, 2 - pelitomorphic limestone, 3 volcanogenic sedimentary rocks, 4 - albitophyres, 5 - dacite, 6 - andesite-dolerite, 7 - andesite-dolerite dikes, 8 - hydrothermallyaltered ore zones, 9 - faults: a) determined, b) assumed, 10 - cut along the A-B line.

The Dagkesaman deposits are confined to the conjunction of two mutually perpendicular structures notable at the basement and Alpine story by the zones of heightened fractures and foliations limiting the flat-parallel blocks of various sizes and amplitudes of movements, different in the degrees of dislocations and metamorphism, concentration of ores and magmatism. At the same time, there are important transversal dips, dip shifts as the main structures of the ore-magmatic systems that contain the major amounts of ores of various types (Baba-zade et al., 2015).

Within the deposits, the ore-containing faults unite into three groups: western, central and eastern. Each group includes four to eight subparallel ore-containing faults that separate the belt structure of dikes of diabases and zones of sulfide mineralization. 
Structural-morphological types of ore bodies. Structural-morphological types of ore bodies may be united into three main groups: 1) simple veins; 2) complex veins; 3) veinlet-impregnation types (Babazade et al., 2006). Simple vein bodies usually have quartzitic and quartz-chalcedony compositions, notable development of simple linear forms, have no apophysis and distinct vein walls. Such veins are mainly confined to the fractures of two strike systems $\left(60-65^{\circ}\right.$ and 230 $300^{\circ}$ ). They are characterized by steep, often near-thevertical dip angles $\left(75-85^{\circ}\right)$, small amount of them have less steep dip $\left(50-60^{\circ}\right)$, mostly $100-150$ to 500 $\mathrm{m}$ long and vary more in thickness, $10-15 \mathrm{~m}$ (rarely $20 \mathrm{~m}$ and more) in places of upswell and $0.5-0.7 \mathrm{~m}$ in places of contraction.

Vein bodies of complex structures are most notable for ores of quartz-carbonate composition, accompanied by thin and short feathering veins and veinlets, located on both vein walls. Similarly to the quartzitic veins, they have distinct contacts, short strike and thickness equaling 50-150 $\mathrm{m}$ and $0.3-0.6 \mathrm{~m}$ respectively (Fig.3). Veins of this type usually pinch out on small distances and ramify in accordance with the form of tectonic fractures. Such veins often have en echelon structure, sometimes being combinations of numerous differentlyoriented thin $(0.1 \mathrm{~m})$ veinlets.

Veinlet-impregnation type of ore-bearing bodies is represented by the zones of fracturing of sulphidized metasomatically-altered volcanogenic rocks that contain quartz and carbonate-quartz veinlets. By their structure, such zones are close to vein bodies of complex structure, but have greater length $(100-500 \mathrm{~m})$ and thickness $(50-150 \mathrm{~m})$. Due to the development of metasomatic processes in these zones, there are no distinct contacts with the containing rocks.

Most of gold ore veins and zones are characterized by steep, often close-to-vertical $\left(75-85^{\circ}\right) \mathrm{dip}$; small amount of them have less steep embedding reaching $50-60^{\circ}$.

Positions of gold ore bodies and their morphological peculiarities are determined by structural factors. The presence of small feathering faults, differentlyoriented systems of fractures and faults which run across the area, gentle curves of these systems and other structural elements - all this promotes localization of gold mineralization. Taking into account that the main ore-bearing zones of deposits are located within the anticline fold and are related to the steeply dipping faults that cross a thick complex of effusive-pyroclastic formations, the localization of strata-like ore seeps in porous pyroclastic rocks directly under covering formations is quite possible (Baba-zade et al, 2006).

Specifics of structural-morphological typization of ore bodies and deposits are determined by their configuration and pattern of sequence of changes with depth. This pattern reflects the direct dependence of the structure and morphology on the relationships with the types of magmatic and metasomatic rocks.

Metasomatic changes in the containing rocks. In the ore zones, the lateral rocks are the ones mostly intensely subjected to various changes in the places where they are represented by andesite porphyrites and their pyroclastolites. The most intensely manifested process is the silicification, reaching the transition of volcanogenic rocks into secondary quartzites and formations similar to them, which have developed around the ore zones, equaling $10-15 \mathrm{~m}$ in width. Sericitization, chloritization, kaolization and calcitation, and of hypergenic changes limonitization are also common in the area. The oreols of altered ore-containing have a zonal structure. The internal zone of kaolinization changes to the periphery by poorly chloritized rocks without notable sulfide mineralization. Sericite, closely related to the process of silicification, develops as scales and sheets between the grains of quartz, sometimes developing individual accumulations there. Kaolinization, particularly chloritization and carbonatization, has a limited development in the zones of ore localization (Babazade et al., 2006; Baba-zade et al., 2015).

Gold, silver and sulfides associated with them are a part of the metasomatism process. Analysis of the data from the wells (№№ 2, 7, 60, 61, 41, 102, 17, 35 and others) and mining works (mine № 8 , mine № 1) indicates that formations near the ore and solfataric facies of secondary quartzites contain gold $(0.2-0.7$ $\mathrm{g} / \mathrm{T})$ (Table 1), and the content of it increases toward the ore zones and quartz-sulfide veins.

Table 1. Chemical-spectral composition of metasomatites of the Dagkesaman deposits

\begin{tabular}{|c|c|c|c|c|c|c|}
\hline \multirow{2}{*}{$\begin{array}{c}\text { Types } \\
\text { of metasomatic rocks }\end{array}$} & \multirow{2}{*}{$\begin{array}{l}\text { Number } \\
\text { of samples }\end{array}$} & \multicolumn{5}{|c|}{ Content of elements } \\
\hline & & $\mathrm{Au}, \mathrm{g} / \mathrm{T}$ & $\mathrm{Ag}, \mathrm{g} / \mathrm{T}$ & $\mathrm{Pb}, \%$ & $\mathrm{Zn}, \%$ & $\mathrm{Cu}, \%$ \\
\hline Mono-quartzous & 14 & 0.25 & 6.6 & 0.12 & 0.4 & 0.12 \\
\hline kaolinitic & 30 & 0.22 & 2.66 & 0.13 & 0.31 & 0.06 \\
\hline chloritic & 10 & 0.3 & 1.6 & 0.14 & 0.6 & 0.3 \\
\hline Near-ore & 70 & 0.7 & 2.8 & 0.10 & 0.25 & 0.04 \\
\hline
\end{tabular}



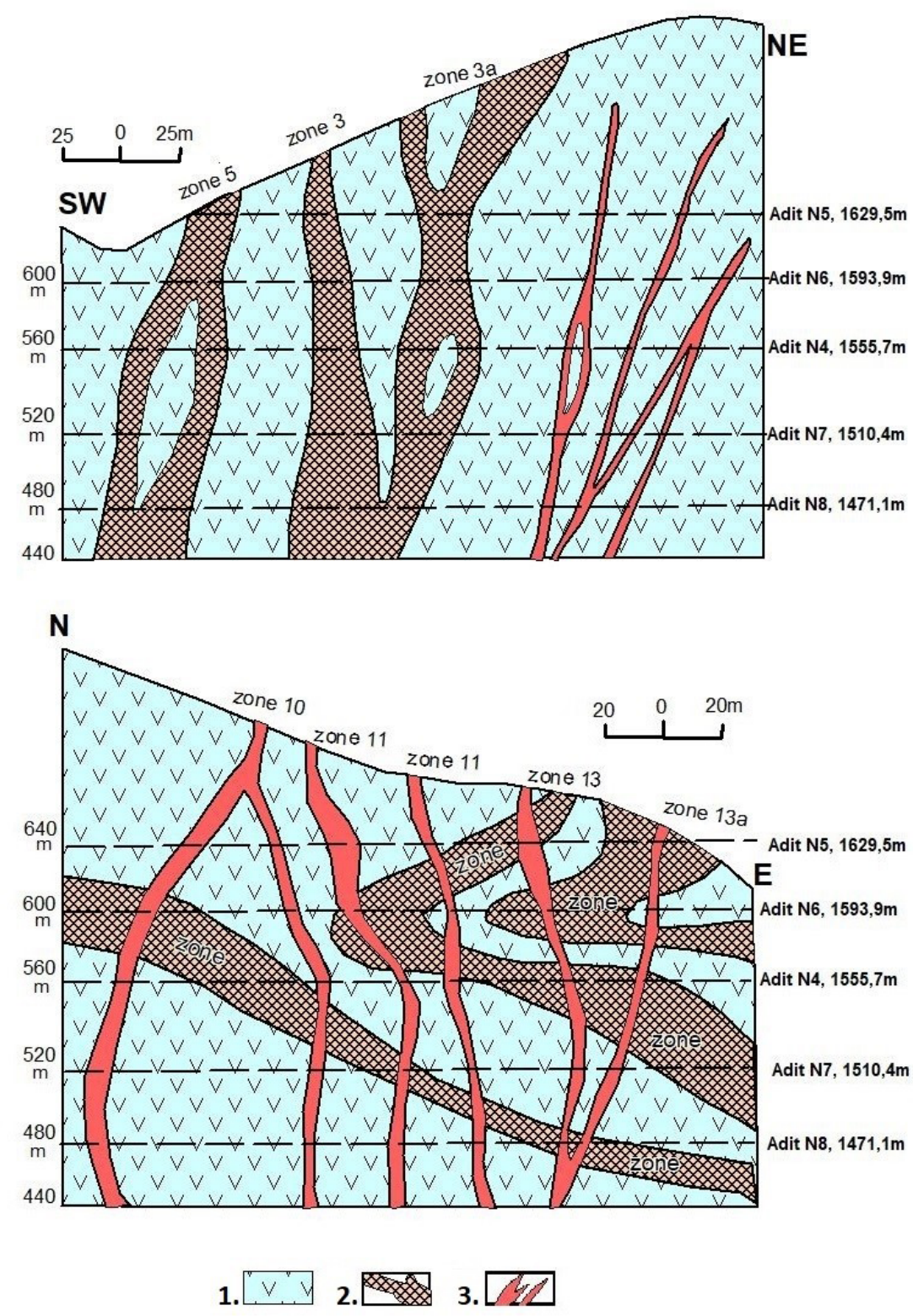

Fig. 3. Structure of ore bodies of the Dagkesaman gold-poly metal deposits: 1 - andesites, 2 - mineralized and vein zones with gold, 3 - quartzous veins and interveins with gold mineralization.

Mineral composition of ore bodies. Analysis of the data on mineralogy and issues of stages of oredevelopment of Dagkesaman deposits was carried out using the results of the earlier studies (Baba-zade et al., 2006; Baba-zade et al., 2015) together with our own observations and additions.

The Dagkesaman deposits of the ore basin are characterized by great variability of mineralogical composition, structures and textures of the ores. About $30 \mathrm{~min}-$ erals were determined in the ores. The main ore minerals are represented by pyrites, sphalerites, chalcopyrites and galenas. The secondary minerals are melnikovites, marcasites, native gold and silver, hematite, polybasite, rutile, magnetite, bornite and other. Vein minerals are represented by quartz, carbonates, barite, chlorite, sericite and muscovite (Baba-zade et al., 2006).
The study of interrelations between the minerals (Ramdor, 1962) allowed us to designate 3 generations of pyrite, chalcopyrite and sphalerite. Generations of pyrite and sphalerite were designated according to the interrelations with chalcopyrite: chalcopyrite appears as cutting veinlets, replacing pyrite-I and sphalerite-I, the borders of its aggregates and grains with pyrite-II and sphalerite-II are even, without corrosive interrelations.

Pyrite-I occurs as impregnations, nest-type thin and short veinlets, characterized by two types. Pyrite-I of average-grained structure comprises shapeless and cubic crystals sized $0.02-0.05$ to $2 \mathrm{~mm}$ (Fig.4a). The second type of pyrite-II is cubic and pentagonal dodecahedron with allotriomorphic-granular structure and forms relatively large aggregates sized 5-6 $\mathrm{mm}$ (Fig. 3b) against the background of fine-grained py- 
rite. Both kinds of pyrite are characterized by uneven distribution, corrosion, brecciation, being crossed by late sulfides. Pyrite-III forms well notable cubic, hexagonal crystals sized $0.05-0.08 \mathrm{~mm}$.

Chalcopyrite-I occurs as small spotty accumulations sized $0.02-0.03$ to $0.2-1 \mathrm{~mm}$ (Fig. $4 \mathrm{c}-\mathrm{d}$ ) in the interstitia of pyrite-I. In the largest grains of chalcopyrite-I, there were seen micro-inclusions of sphalerite-I (decomposition of solid solution), indicating high-temperature regime of their development. In association with pyrite-II, sphalerite-II and galena-I, chalcopyriteII forms spotty and nest-type accumulations (Fig.4e-f). Its crystals are almost isometric and irregular in shape, sized $0.5-0.1$ to $0.2-1 \mathrm{~mm}$, and form structures of mutual strikes with sphalerite-II and galena-I without signs of replacements. Chalcopyrite-III is quite common. Grains sized $0.05-0.08 \mathrm{~mm}$ are in associations with galena-II and gold-II.
Sphalerite-I is seen as small bodies sized $0.04-0.08$ $\mathrm{mm}$. Sphalerite-I in associations with chalcopyrite-I fills the spaces between the grains of pyrite-I, replacing and corroding it. The grains of sphalerite-I often form bud-like concentrations. Sphalerite-II is distinct by large $(1-8 \mathrm{~mm})$ sizes of grains. In association with galena-I, it forms impregnated, spotty and nest-type concentrations.

Galena-I occurs as small plate-like bodies in associations with chalcopyrite (Fig. 4g). Irregular-shaped aggregates are developed extremely unevenly. SphaleriteII and chalcopyrite-II are closely grown together without signs of replacement.

Molybdenite occurs quite rarely. Elongated platelike specimens sized $0.005-0.01 \mathrm{~mm}$ are associated with late quartz (Fig.4h).
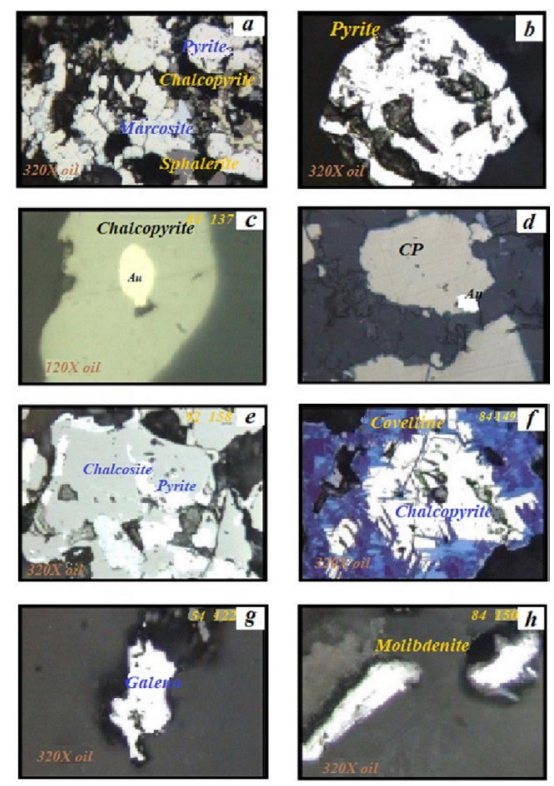

Fig. 4. Fragments of photomicrographic mineralization on Dagkesaman deposits: a-pyrite of average-grained structure, b-cubic shape of pyrite, c-d-chalcopyrite of generation I, e-f-spotty and nest-type accumulations of chalcopyrite, $g$ - plate-type bodies of galena, h-elongated plate-like bodies of molybdenite.

Native gold occurs mostly as veins of collomorphic zonal structure with small xenolithes of containing rocks. Numerous signs (81) of native gold which were found in one of polished section are confined mainly to the stripe before the vein wall of quartz. Under the microscope, gold is seen also in pyrite, sphalerite galena and chalcopyrite; it forms scale-like concentrations in the initial sulfide ores as stripes and spots (Fig. 5). The color of gold is mostly saturated bright yellow, but there brighter grains of yellow color also occur. The shape of gold completely depends on the regions of fractures and small pores it had filled. Size of the bodies varies $0.001-0.05$ to $1 \mathrm{~mm}$, rarely larger. The commonest forms of gold are plate-like, dust-like, sheet-like, and also drop-like and irregular-shaped bodies (Peterovskaia et al., 1976; Akhmedov et al., 2019).

Silver, which was found in the sample of oxidized ores, is represented by several mineral forms, including: free, Au-Ag alloy and rare minerals - jalpaite and stromeyerite. All these substances such as gold are represented by small grains, closely associating mainly with iron oxides (Guseynov, 2019).

Native silver and its minerals in oxidized ores (13 elements) were mainly found in oxides of Fe-Ti and only 3 elements were identified in light fraction (Fig. 6). This indicates that large amount of silver in oxidized ores is closely associated with iron oxides and hydroxides. The identified elements of silver are represented by small grains of $1-8 \mu \mathrm{m}, 5 \mu \mathrm{m}$ on average. By chemical 

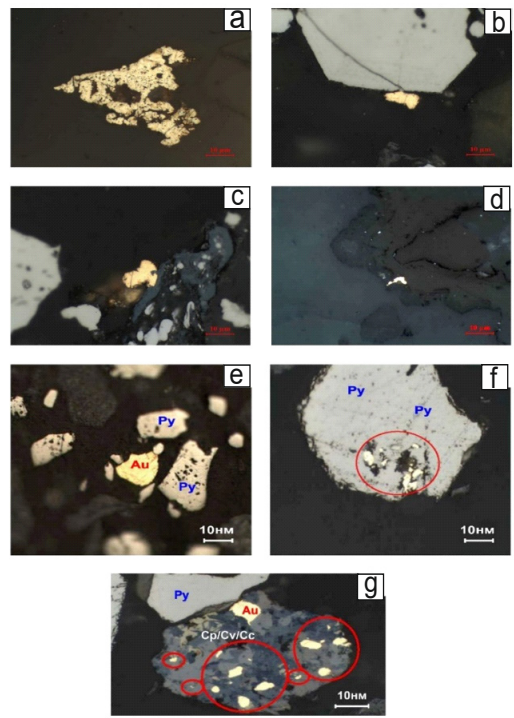

Fig. 5. Photos of gold grains in sample of oxidated ore (Сомр. A): a - large free and partly porous gold, b - free grain near pyrite (Py), c confined to covellite (CV) and dark (unidentified) minerals (NOP), d - free (indicated by red) confined to dark (unidentified) minerals in primary sulfide ores, $\mathrm{e}$ - native gold, $\mathrm{f}$ - inclusions in pyrite (Py), $\mathrm{g}$ - inclusions in chalcopyrite (covellite, chalcocite) $(\mathrm{Cp} / \mathrm{Cy} / \mathrm{Cc})$.

composition, determined using x-ray microanalyzer, 4 grains were characterized as native silver $(\mathrm{Ag}>90 \%)$, 9 grains were $\mathrm{Ag}-\mathrm{Cu}$ alloy $(\mathrm{Ag}>60 \%$, $\mathrm{Cu}$ to $40 \%)$. Furthermore, rarely occurring silver-bearing minerals were found, two of which were characterized as
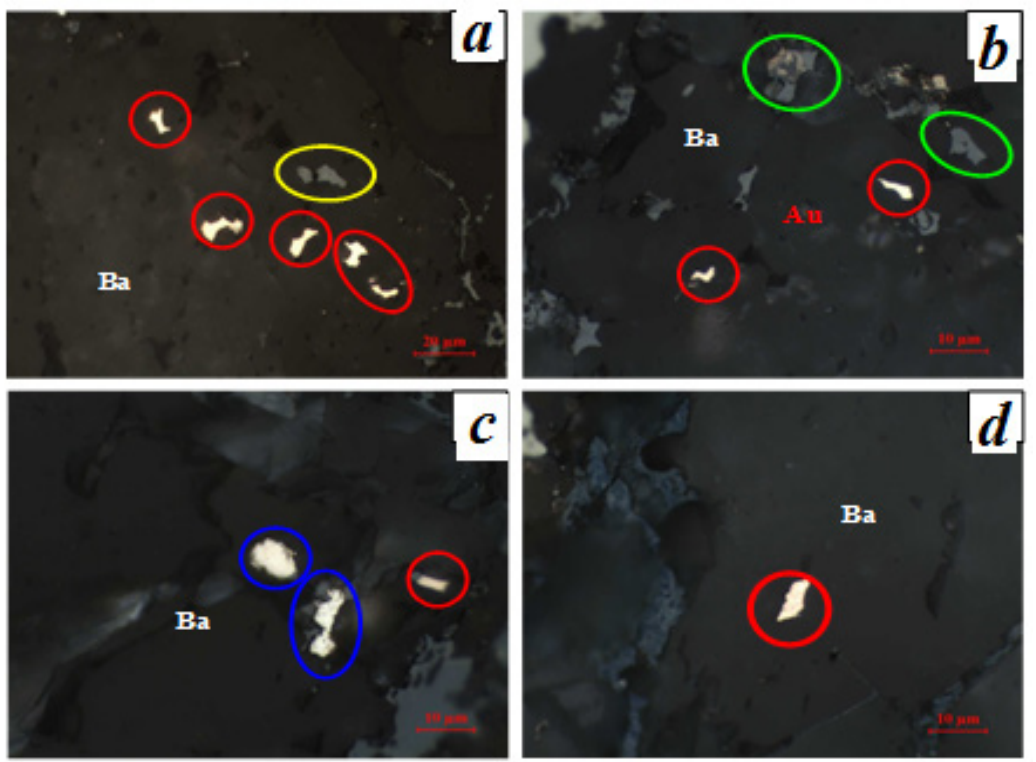

Fig. 6. Microphoto of grains of silver in oxidezed ores (inclusions in barite and in association with barite): a-mixture of $\mathrm{Cu}-\mathrm{Ag}$ alloy (in red circles) and stromeyerite (yellow circles); b-mixture of $\mathrm{Cu}-\mathrm{Ag}$ (in red crcles) and jalpaite (in green circles), $\mathrm{c}-\mathrm{mixture} \mathrm{of} \mathrm{Cu}-\mathrm{Ag}$ (in red circle) and native silver (blue circle), $\mathrm{d}$ - mixture of $\mathrm{Cu}$ - $\mathrm{Ag}$ (in red circle).

As known, the quantitative relationships between gold and silver in ores may serve as indicators of processes of development of minerals and migration ability of silver and gold (Vikinteyev, 2006). Practical significance of $\mathrm{Au}$ : Ag is used in finding elements of hypogenic zonality in some cases, and in assessing ore bodies in depth in other cases. Within the deposits, the jalpaite (Ag-55,7\%; Cu-29,7\%; S-14,5\%), and one as stromeyerite with contents in\%: Ag-55,1; Cu-28,6; S-16,3 (Guseynov et al., 2103; Guseynov, 2019). 
Table 2. Distribution of contents of $\mathrm{Au}, \mathrm{Ag}$ and values of their relations in the containing rocks and ore deposits (in the horizons of adits)

\begin{tabular}{|c|c|c|c|c|c|}
\hline \multirow[t]{2}{*}{ Horizons of adit } & \multirow{2}{*}{$\begin{array}{l}\text { Containing rocks } \\
\text { and ores }\end{array}$} & \multirow[t]{2}{*}{ Number of analysis } & \multicolumn{2}{|c|}{ Elements } & \multirow[t]{2}{*}{$\mathrm{Au}: \mathrm{Ag}$} \\
\hline & & & $\mathrm{Au}$ & $\mathrm{Ag}$ & \\
\hline \multirow[t]{4}{*}{ Adit № 2 (562.2m) } & \multirow[t]{2}{*}{ containing } & \multirow[t]{2}{*}{80} & $0.005-4.0$ & $0.0-26.0$ & \multirow[t]{2}{*}{$1: 12$} \\
\hline & & & $0.14(32.6)$ & $1.2(17.1)$ & \\
\hline & \multirow[t]{2}{*}{ Ore deposits } & \multirow[t]{2}{*}{95} & $0.005-4.3$ & $0.0-72.0$ & \multirow[t]{2}{*}{$1: 4$} \\
\hline & & & $1.2(279.0)$ & $2.9(41.4)$ & \\
\hline \multirow[t]{4}{*}{ Adit № $3(535.4 \mathrm{~m})$} & \multirow[t]{2}{*}{ Containing } & \multirow[t]{2}{*}{90} & $0.005-9.0$ & $0.005-37.0$ & \multirow[t]{2}{*}{$1: 6$} \\
\hline & & & $0.18(41.8)$ & $1.13(16.1)$ & \\
\hline & \multirow[t]{2}{*}{ Ore deposits } & \multirow[t]{2}{*}{100} & $0.005-77.0$ & $0.005-212.5$ & \multirow[t]{2}{*}{$1: 4$} \\
\hline & & & $1.5(348.8)$ & $3.54(50.5)$ & \\
\hline \multirow[t]{4}{*}{ Adit № 8 (411.8m) } & \multirow[t]{2}{*}{ Containing } & \multirow[t]{2}{*}{100} & $0.0-1.6$ & $0.0-13.2$ & \multirow[t]{2}{*}{$1: 12$} \\
\hline & & & $0.12(27.9)$ & $1.6(22.8)$ & \\
\hline & \multirow[t]{2}{*}{ Ore deposits } & \multirow[t]{2}{*}{125} & $0.0-46.4$ & $0.0-86.0$ & \multirow[t]{2}{*}{$1: 3$} \\
\hline & & & $3.8(883.7)$ & $16.0(228.0)$ & \\
\hline
\end{tabular}

Note: in numerator - variation of contents of elements, in denominator - average content, in brackets - clarke of concentrations

The impregnations, striped, veinlet, spotty, massive and brecia textures are distributed in the ores. There rarely occurs cockade texture, which develops in the areas of growth on the fragments of altered rocks and significantly sulfide ores of chalcedony quartz, associated with calcite. Of the ores, we should note granular (allo-and hypidiomorphic), skeletal, loopy and cementing ones (Akhmedov et al., 2019).

\section{Results and discussion.}

Mineralogical analysis of ores of Dagkesaman deposits revealed that the development of gold polymetallic mineralization was relatively long and occurred in several stages. Based on the obtained geologicalstructural data and the study of ores and their texturestructural specifics, there are the following stages of mineral formation (Baba-zade et al., 2006; Baba-zade et al., 2015): I - stages of deposition of the main mass of quartz, and then quartz-pyrite-sericite mineral association II - quartz-galena-sphalerite-gold (polymetallic) ore stage, including quartz-pyrite, sphaleritechalcopyrite-pyrite, gold-chalcopyrite-galena, quartzhematite-magnetite and quartz-carbonate associations.

The research found two productive, subsequently developed mineral associations: quartz-pyrite with disperse gold and gold-chalcopyrite-galena, divided by tectonic movements. Gold-bearing pyrite of early association has catalized to various degrees - from small fractures to small fragments and has been cemented by minerals and poly-sulfide association, which are closely grown together (Volkov et al., 2018).

At the hypergenic stage, minerals of oxidation zone (measuring mostly $20-25 \mathrm{~m}$, sometimes reaching
$30-40 \mathrm{~m})$ as well as zones of secondary enrichment (covellite, argentite, polybasite, stromeyerite, jalpaite and others) are developed in the deposits. At the same time, high concentration of gold in ore zones of oxidation is connected with secondary hypergenic processes (Roslyakov, 1991). Fine-disperse gold (1$10 \mu$ ) occurs as catenate, ameboid bodies. At the same time, native gold is average and fine (90-97 weight.\%), silver -5.6 to 33.1 weight.\% (Guseynov, 2019). Additional elements are $\mathrm{Fe}, \mathrm{Cu}, \mathrm{S}, \mathrm{Bi}, \mathrm{Zn}, \mathrm{Pb}, \mathrm{As}$, Se, Te. Gold fineness varied broadly ( 800 to $950 \%$ ). The following morphology of grains of native gold was identified: homogenous, zonal, mono-grained, spotty. Sometimes, there are crystals of native gold which are represented by octahedrons. These internal structures of native gold are of great practical significance during analysis of genesis of deposits, making predictions, surveys and assessments (Guseynov et al., 2013).

Gold-productive is quartz-pyrite association with disperse gold and, specifically the second mineral association with a close paragenetic relationship between hypogenic noticeable gold and chalcopyrite-galena paragenesis of polymetal stage. Ubiquitous distribution of quartz-pyrite mineral association with thin-disperse gold in the ore zones creates background contents of gold in the deposits, and its increased amounts are confined to the areas of presence of chalcopyrite-galena mineral association with native gold. The contents of silver in ores increase with presence of gold and silvercontaining pyrite and chalcopyrite, sometimes with galena (Table 3). 
Table 3. Chemical composition of some sulfides of the Dagkesaman deposits.

\begin{tabular}{|c|c|c|c|c|c|c|c|c|c|c|c|c|}
\hline \multirow{2}{*}{ Minerals } & \multirow{2}{*}{\begin{tabular}{c|} 
№ \\
sample
\end{tabular}} & \multicolumn{9}{|c|}{ Content, weight $\%$} & \multirow[t]{2}{*}{ Total } & \multirow{2}{*}{ Formula } \\
\hline & & $\mathrm{Fe}$ & $\mathrm{Cu}$ & As & $\mathrm{Ag}$ & $\mathrm{Au}$ & $\mathrm{Zn}$ & $\mathrm{Te}$ & Co & $\mathrm{S}$ & & \\
\hline $\begin{array}{l}\text { Pyrite } \\
\text { (tellurium-containing) }\end{array}$ & $14^{\mathrm{d}}$ & 49.9 & - & - & - & & & 0.03 & & 52.71 & 100.64 & $\mathrm{Fe}_{1.09}\left(\mathrm{~S}_{2.00} \mathrm{Te}_{0.001}\right)_{2.00}$ \\
\hline pyrite & $22^{\mathrm{d}}$ & 46.65 & 0.06 & - & - & & & & & 53.45 & 100.21 & $\left(\mathrm{Fe}_{100} \mathrm{Cu}_{0,001}\right)_{100} \mathrm{~S}_{200}$ \\
\hline $\begin{array}{l}\text { pyrite } \\
\text { (gold- and silver- } \\
\text { containing) }\end{array}$ & $31^{\mathrm{d}}$ & 53.4 & - & 0.02 & 0.006 & 0.012 & & & 0.02 & 46.5 & 99.96 & $\begin{array}{c}\left(\mathrm{Fe}_{1.32} \mathrm{Co}_{0.001} \mathrm{Au}_{0.001} \mathrm{Ag}_{0.001}\right)_{1.32} \\
\left(\mathrm{~S}_{2.00} \mathrm{As}_{0.004}\right)_{2.00}\end{array}$ \\
\hline Chalcopyrite & $22^{\mathrm{d}}$ & 30.42 & 34.74 & - & - & & 0.05 & & & 34.65 & 99.86 & $\left(\mathrm{Cu}_{101} \mathrm{Fe}_{101} \mathrm{Zn}_{0,001}\right)_{201} \mathrm{~S}_{200}$ \\
\hline Chalcopyrite & $31 \mathrm{~d}$ & 30.1 & 34.4 & 0.03 & 0.0009 & 0.008 & & & & 34.1 & 98.65 & $\begin{array}{c}\left(\mathrm{Cu}_{1.02} \mathrm{Fe}_{1.01} \mathrm{Ag}_{0.001} \mathrm{Au}_{0.001}\right)_{2.00} \\
\left(\mathrm{~S}_{200} \mathrm{As}_{001}\right)_{200}\end{array}$ \\
\hline Sphalerite & $22^{\mathrm{d}}$ & 1.06 & 0.03 & - & - & & 65.21 & & & 33.42 & 99.71 & $\left(\mathrm{Zn}_{006} \mathrm{Fe}_{002} \mathrm{Cu}_{001}\right)_{090} \mathrm{~S}_{100}$ \\
\hline Sphalerite & $22^{\mathrm{d}}$ & 0.02 & 0.03 & - & - & & 65.1 & & & 33.42 & 98.67 & $\left(\mathrm{Zn}_{0.96} \mathrm{Cu}_{0.001} \mathrm{Fe}_{0.001}\right)_{0.97} \mathrm{~S}_{1.00}$ \\
\hline
\end{tabular}

Development of gold took place during the sulfide stage, which manifested in the production of quartz-pyrite paragenesis (disperse gold), replaced by chalcopyrite-galena (with hypogenic notable gold) polymetallic stage, then quartz-chalcocite and has been completed by poorly manifested late quartz, calcite and barite (Imamverdiyev et al., 2013). Criteria for determining the generations are interruptions in crystallization of minerals, related to the internal ore tectonic movements and changes in acidity of the solutions and development of the main amounts of sulfides and quartz (Naumov et al., 2016; Nenakhova, 2016).

The general tendency of the evolution of physicalchemical conditions in the process of multi-stage hydrothermal mineral formation in the Dagkesaman deposits is the continuous decrease in the temperatures and pressures with inversions, accompanied by changes in the content of the main components that had separated from the ore-generating center of the fluids. Thermodynamic parameters and complex aggregate condition of mineralforming fluids during the development of polymetallic mineralization may be explained by the likely temporal closeness of shift of hydrotherms and endogenous ore development (Naumov, 2016; Filipov et al., 2013; Malakhov, 1979).

The main ore-providing canal is the Eastern fault. This was also confirmed by the results of decrepitation of the vein quartz (Karayeva, 1976), indicating that high temperatures of occurrence of faults $\left(300^{\circ} \mathrm{C}\right)$ fixate in the northeast flank, near the contact with rhyodacites, whereas the temperatures of hydrotherms decrease along the zone and in the southwest direction. At the same time, there was determined that the "tempo of cooling of quartz-forming fluids in the vein is $\sim 1^{\circ}$ per $10 \mathrm{~m}$ ". These data, obtained according to the results of fracturing of vein quartz, explicitly indicate the orientation of the movement of ore-bearing fluids and the position of ore-providing canal (Malakhov, 1979).

In general, the results of micro-thermometric studies indicate (Karayeva, 1976; Malakhov, 1979) that the initial temperature of hydrothermal fluids that have deposited the mineral associations of the first (quartzpyrite-sericite) stages varied within $300-240^{\circ} \mathrm{C}$, and the decrepitation occurred in the temperature of $280^{\circ} \mathrm{C}$. Homogenization of the primary gas-liquid inclusions in quartz took place in $240-260^{\circ} \mathrm{C}$ interval. Quartzgalena-sphalerite-gold ore stage had begun with deposition of a large amount of quartz in the temperature of $260-220^{\circ} \mathrm{C}$, and then galena deposited, forming in the temperature of $220^{\circ} \mathrm{C}$, and finally has been completed by crystallization of chalcopyrite and sphalerite in $160^{\circ} \mathrm{C}$. Gold that is found with all the mentioned minerals of this stage was formed in the temperature interval of $220-160^{\circ} \mathrm{C}$ (Baba-zade et al., 2015).

The ores of the Dagkesaman deposits have been formed in the conditions of temperature falling from $300^{\circ} \mathrm{C}$ to $160^{\circ} \mathrm{C}$ out of low-salted hydrothermal fluids that contained chlorides $\mathrm{Na}, \mathrm{K}$ and $\mathrm{Mg}$, with insignificant inclusion of $\mathrm{CO}_{2} \mathrm{HS}^{-}, \mathrm{CH}_{4}$, against the background of their dilution and mixing with meteor water (Novruzov et al.,). The same conditions are the most favorable for deposition of minerals and sedimentation of $\mathrm{Au}$ and Ag (Borisenko et al., 2017; Volkov et al., 2018).

Significantly sulfide veins with sulfides amounting to about $50-70 \%$ are the commonest and therefore the Dagkesaman deposits may be classified as the formation of gold-quartz-polysulfide (Baba-zade et al., 2015) or significantly sulfide ores (Petrovskaya et at., 1976). Presence of a large amount of gold in the ore zones of oxidation and partly in the pseudomorphoses of goethite and lepidocrocite in pyrite, which is the result of the decomposition of sulfuric pyrite that contains thin-disperse gold, may be an indirect evidence of presence of thin-disperse gold in pyrite-II of quartzpolymetallic stage of the development, enlarged in the process of redeposition.

\section{Conclusions.}

The most important conclusions of the study of the conditions of localization and patterns of arrangement of gold-polymetallic mineralization, mineral composition 
and paragenesis of altered and mineralized zones in the Dagkesaman deposits and issues of their epithermal type are as follows:

- gold-polymetallic mineralization is mostly of vein and veinlet-impregnation type;

- mineralization is distributed quite unevenly within the ore bodies, forming relatively small sulfide-enriched regions that quickly become displaced along the dip and strike;

- mineralization is spatially related to albitophyres of subvolcanic facies. Based on monitoring made over the mineralogical studies, polymetallic ores include various types of mineralization (vein, veinlets, impregnations), usually after identifying the period of the stage of impregnated pyrite;

- near-ore processes of the containing rocks are manifested in hydrothermal-metasomatic changes (silicification, sericitization, chloritization, kaolization) up to transformation into the secondary quarcites;

\section{References}

Abdullayev, R.N., Mustafayev, G.V., Mustafayev, M.A. et al., 1988. Mezozoyskie maqmaticeskie formatsii Malogo Kavkaza i svyazannoe s nimi endogennogo orudenenie [Mesozoic igneous formations of the Lesser Caucasus and associated endogenous mineralization]. Baku: Izdvo. Elm, 254 (In Russian).

Akhmedov, A.Z., Kitachayev, Sh.M., Shibayeva, A.A. et al., 2019. Material composition and technological aspects of ores of Dagkesaman gold field (Lesser Gaucasus). Azerbaijan National Academy of Sciences Transactions Earth Sciences. Baku: 2, 36-46.

Baba-zade, V. M. Kekeliya, S.A., Abdullayeva Sh. F. et al., 2015. Zolotosoderzhashie sulfidnye mestorozhdeniya ostrovoduzhnyx paleosistem, ix metallogenicheskie osobennosti i usloviya geodinamicheckogo pazvitiya (na primere Alpid Malogo Kavkaza) [Gold-bearing sulfide deposits of island-are paleosystems, their metallogenic features and conditions of geodynamic development (for example, Alpid of the Lesser Caucasus)]. Baku: Izd-vo. CBS-PP, 309 (In Russian).

Baba-zade, V.M., Ramazanov, V. Q. Mansurov, M. I., 2006. Dagkesamanskiy rudniy uzel - perspektivnaya metallogenicheskaya yedinitsa Somkhito-Karabakhskoy zony Malogo Kavkaza [Dagkesaman ore cluster is a promising metallogenic unit of the Somkhito-Karabakh zone of the Lesser Caucasus]. Vestnik Bakinskogo Universiteta, seriya yestestvennykh nauk. 1, 74-85 (In Russian).

Borisenko, I. D., Borovikov, A.A., Borisenko, A.S. et al., 2017. Fiziko-khimicheskie usloviya formirovaniya rud Samolazovskogo mestorozhdeniya zolota (Tsentralniy Aldan) [Physicochemical conditions for the formation of ores of the Samolazovskoye gold deposit (Central Aldan)]. Geologiya i Geofizika. 58 (12), 1915-1927 (In Russian).

Filippov, A., Ryabinin V. F., Sysoeva Z. Z. 2013. Gagarskoe zolotorudnoe mestorozhdenie na Srednem Urale, Rossiya [Gagarskoe gold ore deposits in the Middle Urals,
- the main ore-forming minerals of the deposits are pyrite, galena, sphalenite, chalcopyrite, represented by several generations. The ores correspond to the products of quartz-pyrite-sericite, sphaleryte-chalcopyrite-pyrite and gold-chalcopyrite-galena stages of mineralization, divided by tectonic movements;

- impegnations, striped, veinlet, spotty, massive and brecia textures; brecia texture occuring mostly at the intermediate and deeper levels are distributed in the ores;

- the ores of the Dagkesaman deposits have been formed out of poorly-soluble hydrothermal fluids that contain chlorides $\mathrm{Na}, \mathrm{K}$ and $\mathrm{Mg}$ in the conditions of $300^{\circ} \mathrm{C}$ to $160^{\circ} \mathrm{C}$ decrease in the temperature.

Taking into account the aforesaid, we may presume that the Dagkesaman gold-poly metal deposits may be identified to epithermal system of high sulphidation.

Russia]. Geologiya rudnykh mestorozhdeniy. 55 (1), 33-47 (In Russian).

Geologiya Azerbaidzhana. Tektonika., 2005. [Geology of Azerbaijan, Tektonika]. Baku: Izd-vo Nafta - Press. 505 (in Russian).

Guseynov, G. S. 2019. Raspredelenie blaqorodnykh metallov $(\mathrm{Au}, \mathrm{Ag}) \mathrm{v}$ Dagkesamanskom zoloto-polimetallicheskim mestorozhdeniya (Azerbaydzhan) [Distribution of noble metals (Au, Ag) in the Dagkesaman gold-base metal deposit (Azerbaijan)]. Gorno-geologicheskoy zhurnal. 4, 29-34 (In Russian).

Guseynov, G. S., Mansurov M. I., Guseynov A. I., 2013. Probnost, elementy-primesi i vnutrennee stpoenie samorodnogo zolota Dagkesamanskogo mestorozhdeniya (Maliy Kavkaz) [Fineness, additional elements and internal structure of native gold from the Dagkesaman deposit (Lesser Caucasus)]. Izvestiya vysshikh uchebnykh zavedeniy Severo-Kavkazskoy region. Seriya Yestestvennykh nauk. № 3, 63-67 (In Russian).

Imamverdiyev, N. A., Musayev Sh. D., Mansurov, M.I., 2015. Sredneyurskiy ostrovoduzhniy vulkanizm i svyazannoe s nimi zolotoe orudenenie Chovdarskoy ploshadi (Maliy Kavkaz, Azerbaydzhan) [Middle Jurassic island-arc volcanism and associated gold mineralization of the Chovdar area (Lesser Caucasus, Azerbaijan)]. Otechectvennaya geologiya. 1, 43-56 (In Russian).

Karayeva, G.A., 1976. Mikrotermometricheskie issledovaniya glavnykh mineralov Dagkesamanskogo polimetallicheskogo mestorozhdeniya [Microthermometric studies of the main minerals of the Dagkesaman polymetallic deposit]. Dokl. AN. Azerb. SSR. 8. 35-38 (In Russian).

Malakhov, V.V., 1979. Termobarigeokhimicheskie usloviya obrazovaniya zolotykh i zoloto-serebdyanykh mestorozhdeniy [Thermobarogeochemical conditions of the formation of gold and gold-silver deposits]. 
V kn: "Fiziko-khimicheskie usloviya endogennogo rudoobrazovaniya" M: Nauka. 99-127 (In Russian).

Naumov, V.B., Girris, A.V.. Dorofeeva, V.A. et al., 2016. Kontsentratsiya rudnykh elementov v magmatisheskikh rasplavakh i prirodnykh flyidakh po dannym izucheniya vklyucheniy $\mathrm{v}$ mineralakh. [Concentration of ore elements in magmatic melts and natural fluids according to the study of inclusions in minerals].Geologiya rudnykh mestorozhdeniy. 4, 367-384 (In Russian).

Nenakhova, E.V., 2016. Mineralniy sostav rud i usloviya formirovaniya kvartsevykh zhil c zoloto-serebryanoy mineralizatsiey Milogradskogo rudoproyavleniya (Primorskiy kray) [Mineral composition of ores and conditions of formation of quartz veins with gold-silver mineralization of the Milogradsky ore (Primorsky Territory)]. Vestnik Voronezhskogo gosudarstvennogo universiteta. Seriya Geologiya. 4, 62-67 (In Russian).

Novruzov, N., Valiyev, A., Bayramov, A., Mammadov, S., Ibrahimov, J., 2019. Mineral composition and paragenesis of altered and mineralized zones in the Gadir low sulfidation epithermal deposit (Lesser Caucsaus, Azerbaijan). Iranian Journal of Earth Sciences. 14-19.
Petrovskaya, N.V., Safonov, Yu. G., Sher, S.D., 1976. Formatsii zolotorudnykh mestorozhdeniy. [Formations of gold deposits]. V kn: Rudnye formatsii endogennykh mestorozhdeniy. M: Izd-vo. Nauka. 3-110 (In Russian).

Ramdor, P. 1962. Pudnye mineraly i ikh srastaniya [Ore minerals and their intergrowths]. M.: Izd-vo. Inostr. Liter. 11-32 (In Russian).

Roslyakov, N.A. 1991. Geokhimiya zolota v zone gipergeneza [Geochemistry of gold in the hypergenesis zone]. Novosibirsk: Izd-vo. Nauka. 238s. (In Russian).

Vikinteyev, I. V., 2006. Formy naxozhdeniya i usloviya kontsentrirovaniya blaqorodnykh metallov v kolchedannykh rudakh Urala [Forms of occurrence and conditions of concentration of noble metals in pyrite ores of the Urals.]. Geologiya rudnykh mestorozhdeniy, 48 (2), 91-125 (In Russian).

Volkov, A.V., Savva, N, E., Kolova E. E., et al., 2018. $\mathrm{Au}-\mathrm{Ag}$ epitermalnoe mestorozhdenie Dvoynoe (p-ov Chukotka, Rossiya) [Au-Ag epithermal deposits Dvoinoe (Chukotka Peninsula, Russia)]. Geologiya rudnykh mestorozhdeniy, 60 (6), 590-609 (In Russian). 